4. Skovorodnikov, A. P. (2000). K stanovleniju sistemy lingvoekologicheskoj terminologii [On the genesis of the system of ecolinguistic terminology]. Spetsializirovannyj Vestnik Krasnoyarskogo gos. un-ta [Specialized herald of Krasnoyarsk state university]. Krasnoyarsk, pp 70-78. (in Russian)

5. Belozerova, N. N., Labunets, N. V. (2012). Ecolingvistika: v poiskah metodov issledovaniya [Ecolinguisrics: seeking for methods of research]. Tyumen: Tyumen University Press, 256 p. (in Russian)

6. Grice, H. P. (1975). Logic and Conversation. In P. Cole, \& J. L. Morgan. (Eds.), Syntax and Semantics, Vol. 3, Speech Acts (pp. 41-58). New York: Academic Press.

7. Leech, G. N. (1983). Principles of pragmatics. New York: Longman Group Limited, $250 \mathrm{p}$.

8. Brown, P., Levinson, St. (1987). Politeness: some universals in language usage. Cambridge: Cambridge University Press, 345 p.

9. Solodovnikova, N. G. (2010). Ekologichnost' emotivnoy kommunikatsii (na materiale predvybornyh kreolizovannyh gazetnayh tekstov) [Eco-friendliness of emotive communication (as exemplified in pre-election creolized newspaper texts)] (PhD Thesis), Volgograd: Volgograd State Pedagogical University.

\title{
THE PROBLEM OF LIFE AND DEATH IN L.ULITSKAYA'S NOVEL «DANIEL STEIN, INTERPRETER»
}

\section{Yuliia Kovryha ${ }^{1}$}

DOI: https://doi.org/10.30525/978-9934-26-002-5-15

The novel «Daniel Stein, interpreter» is, of course, a story about a human life full of happiness and sorrows, love and hate, forgiveness and resentment. This is a novel about quite difficult period in the life of Soviet society associated with the events of World war II, being in the ghetto, executions, and concentration camps. In addition to the political hardships of life, the characters face other problems related to life in an orphanage and the consequences of this, misunderstandings between children and parents, payment for sins, etc. Concerning the problem of «fathers and children», L. Ulitskaya shows that blood ties are not the key to a good relationship. There are often insults, misunderstandings, and even hatred between relatives who are presented as novel characters. Giving characters' «confessional» letters, the writer represents the idea that a good relationship is a daily work; it takes a lot of effort to understand the other, forgive and love.

\footnotetext{
${ }^{1}$ Kharkiv National Agrarian University named after V. V. Dokuchaiev, Ukraine
} 
And above all these particular problems is a question of a philosophical order - the problem of life and death.

Through the entire novel passes the idea of the evolution of human world perception. Almost all the characters in the work are characterized by some internal transformation. This process is quite long and sometimes painful, when you realize that life was lived wrong, that what you devoted your life to had no sense. It is extremely difficult for the novel characters to deviate from the usual course of thoughts and accept new ideas, which entails a violation of stability and the established life balance: «Not everyone is ready to accept new ideas, specify knowledge, supplement. In general - to change» [1, p. 372]. But Ulitskaya postulates the thought that no matter how painful the process of internal transformation is, it is inevitable.

On the examples of characters' life in the novel, we can make sure that this process consists of such stages as awareness, acceptance, and transformation. Let's look at them in more detail.

At the stage of awareness, the character begins to understand that something does not suit him in life. He does not yet imagine his future life, does not see a way out, but «the spirit of resistance to the world's vulgarity» already lives in him [p. 88]. This stage is a kind of inner rebellion of the restless soul: «I'm also 16, but I don't know yet what model I want to build my life on. Definitely not according to yours» [1, p. 638].

The continuation of this stage is presented in the novel in 2 variations.

1) If during this period there is no person near you who can help to cope with the "collapse of the world», then the ending can be tragic, as in the case of Binyomin Shimes, who, having faced the cruelty and bloodiness of the world, hanged himself at home.

2) The presence of such person gives hope for a better end, which can be seen in the example of Eva Manukyan. Having realized that her son is gay, she does not understand how to live further. But during this difficult period of her life, Daniel was a person who was able to find the right words and helped her survive the crisis.

At the stage of awareness, the past is of no small importance. From the author's point of view, understanding of your past is the key to the spiritual health of the nation. Without understanding of the past mistakes, it is impossible to move forward. And if the stage of awareness, no matter how painful it may be, passes successfully, the character moves to a new stage of transformation - the stage of acceptance.

At this stage, the new knowledge becomes part of the character itself, he no longer rebels, begins to think about how to build his life in connection with the acceptance of a new situation. This stage differs from the previous one in 
the absence of painful sensations and experiences. It becomes the beginning of healing.

The stage of transformation is marked by the formation of a new worldview in the hero, we can say, the formation of a new person. So, for Eva, it becomes absolutely normal when her son and his boyfriend come down to breakfast. The heroine's acceptance of the situation led to deliverance from mental suffering. She's free now.

In addition, at the stage of transformation, the characters comprehend the «integrity of life», there is no longer a division into «significant» and «insignificant», everything has the same importance, «...or rather, what you are doing at this very moment is significant» [1, p. 296], because at this moment you are at the center of life.

The novel «Daniel Stein, interpreter» is not only a story about life, its difficulties and crises. It is also a story about death and its many faces. The theme of death, the problem of a person's attitude to death, take a prevailing place in the novel. Ulitskaya tells about various deaths, paying special attention to the inner state of a person who got in touch with phenomenon.

It is extremely important for the author to watch the state of a person who is on the verge of death. She wants to look inside and find out what her character feels, what he thinks about at the moment when his life may end.

The novel presents a kaleidoscope of deaths, which are presented in the novel in two variations - violent and non-violent. The first type of death dominates the war, it is cruel, «full of animal fear» and forcibly «roots» relatives and friends out of the family. Death of the second type is the natural end of life, it is blessed, because it signifies a joyful meeting with God: «<.. > I clearly saw into whose hands I was handing them over. They were being met by Heavenly Forces, and they were leaving with happy faces» [1, p. 184]. This is what death is like in the «undistorted world». And this natural death should not be frightening, and the attitude towards it should be calm.

But we must admit that natural deaths in the text of the novel are quite rare phenomenon, mostly we encounter violent ones when the characters pass away at a young age. Of course it's unnaturally, but in this way the author wants to emphasize that the life itself is very fragile and may end at any moment.

It is important to note that in the text of the novel we also deal with thanatological reflection, when the characters begin to reflect on their death, imagine it and express their attitude to this event. For example, one of the characters, realizing that her life is melting and the earth's term is coming to an end, experienced «death horror - animal, piercing through», which was causing nausea [1, p. 334]. She was completely unprepared for what was happening to her, in her understanding the death should be different - calm and with a prayer on her lips. She was dying excruciatingly painful: 
«the joyful and elated state was replaced by such weakness, physical and spiritual», that she experienced nothing but attacks of fear. During this period, the thought of her own death was simply unbearable, the only hope was prayer, and Teresa tirelessly appealed to the Almighty for salvation: «Let the worst happens, even if I am expelled from the convent, just don't let me die now...». [1, p. 334]. Her prayers were heard, after three months she recovered, but at the same time, she was really expelled from the convent.

An important aspect of thanatological reflection in the novel is the question of preparation for death. In one of Lyudmila Ulitskaya's letters to Yelena Kostyukovich, which is included in the novel, the addresser mentions the request for «a Christian decease, peaceful, unashamed and painless» as the most important of all requests addressed to God [1, p. 416]. By making this request to God, a person realizes the transience and finality of his life and begins to prepare for its last day.

And this preparation is not limited only to a request, it is many-sided. One of its stages, according to Ulitskaya, is physical suffering as an atonement for sins: «But before death, how good it is to get sick, cleanse, and prepare» [1, p. 435]. Patiently undergoing the death agony, a person is more clearly aware of his sins and has the opportunity to repent. After all, only humility and repentance can open the Kingdom of Heaven for him.

Repentance and absolution for the sins is of paramount importance for any believer whose mundane life is coming to an end. For example, it isn't accidentally that one of the characters - Rita Kovach, who has been a zealous communist all her life, comes to the end of her life to a thought about the need for communion with God. This is another example of internal transformation process that we discussed earlier: «Of course, this will surprise you, but for me this event is prepared by the whole course of my life, it is not accidental, but natural, and I am happy that I did not die before my baptism» [1, p. 416]. Only with the adoption of baptism, her restless soul found peace and pacification; now Rita did not worry «neither for her life nor for her death», she was in God's hands [1, p. 416]. Only when one is reconciled to God a person overcomes the fear of death.

The motive of penance in the novel «Daniel Stein, interpreter» correlates with the motive of retribution for the deed. Ulitskaya represents the seemingly banal idea that a person's mundane actions can open the Kingdom of Heaven for him, or cast him into eternal Hell. The essence of these acts is reduced not only to prayers and good thoughts, but to a greater extent to specific deeds and actions: "When our land becomes dilapidated and is rolled up like an old carpet, when dry bones arise, we will be judged not by the language in which we prayed, but by whether we found compassion and mercy in our hearts» [1, p. 352]. By implicitly introducing into her text the idea that the road to hell 
is paved with good intentions, the writer makes it clear to her reader that desires and intentions alone are not enough to save the soul.

Having analyzed all the above, we come to the conclusion that L. Ulitskaya's novel «Daniel Stein, interpreter» is a novel in the center of which a number of important issues of existential order and the problem of life and death takes one of the dominant places in this series. Without a doubt, the most important conclusion of this book, in the context of the studying issue, is that death is as natural stage of life as any other (childhood, youth, maturing). You don't need to be afraid of this, on the contrary, you need to remember it. From the author's point of view, all mundane life is a preparation for this event.

\section{References:}

1. Ulitskaya, L. (2011). Daniel Stein, interpreter. Moscow: Eksmo.

\section{ENGLISH LANGUAGE TERMINOLOGICAL SYSTEM: PROBLEMS DEFINITION AND CLASSIFICATION OF TERMS}

\section{Inna Pylypenko ${ }^{1}$}

DOI: https://doi.org/10.30525/978-9934-26-002-5-16

With the growth of human knowledge and the development of ideas, as well as their change, the number of words in the language increases. Each new scientific discovery needs a name as a means of expressing a logical idea of the concept. This process also causes numerous changes in the meanings of existing words. English, like any other language, adapts to a wide variety of definition needs. The vocabulary of the language determines the possibilities for the expression of certain concepts or objects for their precise and expressive definition. The lack of definition of a known concept in language is one of the biggest obstacles to its transmission in language. Usually, these obstacles are overcome by creating a new word or borrowing a word from another language. Such replenishment of vocabulary occurs constantly, crystallizing in words all that has been deposited in the public consciousness. Each area of life and knowledge is characterized by its range of names, which should be mastered by everyone who deals with them. The need for names is an elementary condition for the accuracy of the language itself.

\footnotetext{
${ }^{1}$ Bila Tserkva National Agrarian University, Ukraine
} 